\title{
Taxonomic utility of old names in current fungal classification and nomenclature: Conflicts, confusion \& clarifications
}

\begin{abstract}
Dayarathne $\mathrm{MC}^{1,2}$, Boonmee $\mathrm{S}^{1,2}$, Braun $\mathrm{U}^{7}$, Crous $\mathrm{PW}^{8}$, Daranagama DA ${ }^{1}$, Dissanayake AJ ${ }^{1,6}$, Ekanayaka $H^{1,2}$, Jayawardena $\mathbf{R}^{1,6}$, Jones $\mathbf{E B G}^{\mathbf{1 0}}$, Maharachchikumbura $\mathrm{SSN}^{5}$, Perera $\mathrm{RH}^{1}$, Phillips $\mathrm{AJL}^{\mathbf{9}}$, Stadler $\mathbf{M}^{11}$, Thambugala $\mathrm{KM}^{1,3}$, Wanasinghe $\mathrm{DN}^{1,2}$, Zhao $\mathrm{Q}^{1,2}$, Hyde $\mathrm{KD}^{1,2}$, Jeewon $\mathrm{R}^{12^{*}}$
\end{abstract}

\footnotetext{
${ }^{1}$ Center of Excellence in Fungal Research, Mae Fah Luang University, Chiang Rai 57100, Thailand

${ }^{2}$ Key Laboratory for Plant Biodiversity and Biogeography of East Asia (KLPB), Kunming Institute of Botany, Chinese Academy of Science, Kunming 650201, Yunnan China ${ }^{3}$ Guizhou Key Laboratory of Agricultural Biotechnology, Guizhou Academy of Agricultural Sciences, Guiyang 550006, Guizhou, China

${ }^{4}$ Engineering Research Center of Southwest Bio-Pharmaceutical Resources, Ministry of Education, Guizhou University, Guiyang 550025, Guizhou Province, China Department of Crop Sciences, College of Agricultural and Marine Sciences, Sultan Qaboos University, P.O. Box 34, Al-Khod 123, Oman

${ }^{6}$ Institute of Plant and Environment Protection, Beijing Academy of Agriculture and Forestry Sciences, No 9 of ShuGuangHuaYuanZhangLu, Haidian District Beijing 100097, China

${ }^{7}$ Martin Luther University, Institute of Biology, Department of Geobotany, Herbarium, Neuwerk 21, 06099 Halle, Germany ${ }^{8}$ Westerdijk Fungal Biodiversity Institute, Uppsalalaan 8, 3584 CT Utrecht, The Netherlands.

${ }^{9}$ University of Lisbon, Faculty of Sciences, Biosystems and Integrative Sciences Institute (BioISI), Campo Grande, 1749-016 Lisbon, Portugal.

${ }^{10}$ Department of Entomology and Plant Pathology, Faculty of Agriculture, Chiang Mai University, 50200, Thailand

${ }^{11}$ Helmholtz-Zentrum für Infektionsforschung GmbH, Dept. Microbial Drugs, Inhoffenstrasse 7, 38124, Braunschweig, Germany

${ }^{*}{ }_{12}$ Department of Health Sciences, Faculty of Science, University of Mauritius, Reduit, Mauritius.
}

Dayarathne MC, Boonmee S, Braun U, Crous PW, Daranagama DA, Dissanayake AJ, Ekanayaka H, Jayawardena R, Jones EBG, Maharachchikumbura SSN, Perera RH, Phillips AJL, Stadler M, Thambugala KM, Wanasinghe DN, Zhao Q, Hyde KD, Jeewon R. 2016 - Taxonomic utility of old names in current fungal classification and nomenclature: Conflicts, confusion \& clarifications. Mycosphere 7(11), 1622-1648, Doi 10.5943/mycosphere/7/11/2

\section{Abstract}

Fungal taxonomy has a long history and nomenclatural type specimens constitute an integral part of fungal classification and nomenclature. To date, type specimens/old names have served as excellent exemplars and references and have been the pillar for a stable classification and appropriate nomenclature. However, with an increase in the number of species being discovered and the practical problems associated with re-examination and over reliance of old names as exemplars, there is a need to reconsider our traditional taxonomic thinking towards such an approach. It is becoming increasingly clear that loaning specimens, especially of rare and old species, is becoming too tedious, difficult and in some cases, practically impossible. This paper addresses in detail some of the major practical difficulties in referring to old names from a stable nomenclatural system viewpoint, in particular, reluctance of herbaria to loan specimens and poor conditions of specimens. Specific case studies where problems are encountered that hinder references to old names are discussed. Last but not least, mycologists express their opinions and 
concerns and provide deductive conclusions based on facts and their long experience in mycology. With regards to fungal nomenclature, taxonomists, devoted to bring about rational changes to fungal taxonomy, should be encouraged to use more friendly and practical approaches, with minimum hassle to examine old specimens. We contemplate that this paper will provide potential solutions to facilitate future naming/classification of fungal species.

Key words - type species - type materials and specimens - species nomenclature -taxonomy DNA sequence data - phylogeny

\section{Introduction}

\section{Using old names - why and what is expected}

The total number of fungal species is estimated to be about 1.5-5.1 million (Tedersoo et al. 2014) and at least 100,000 species of fungi have been described, but the global numbers of fungi is not very well understood (Ravichandra 2013). Names applied to species are the key to all accumulated knowledge, their different characteristics, and uses (Jayasiri et al. 2015). Names act as the communication tool in all aspects of biology (Hawksworth 2001, Jayasiri et al. 2015). Binomial nomenclature was introduced by Carolus Linnaeus and is applied to formally recognize fungi as is usual for the nomenclature of all organisms (McNeill et al. 2012). All fungal names are based on the principle of priority and only one scientific name is now allowed for a species or genus, in accordance with the other groups of organisms governed by the International Code of Nomenclature for algae, fungi, and plants (ICN) (Rossman et al. 2015). Names can be based on distinct characters, host species association, the locality or personal names (as an honour to another mycologist) or other preferences of individuals (e.g. Leptosphaeria italica - reflects the country Italy; Halorosellinia rhizophorae- referring to the host genus Rhizophora).

It is also a requirement to consider the gender (feminine, masculine and neuter) in fungal nomenclature (McNeill et al. 2012). Fungal names are fixed to a taxon by a type and dried fungal material in any form (e.g an image or a preserved dry culture or a TEM resin block) should be deposited and preserved in a herbarium (McNeill et al. 2012). Some type collections can be viewed online on websites hosted by herbaria (McNeill et al. 2012), but for microfungi, this is of little use as it does not allow re-examination of specimens to validate or verify their taxonomy. Names and epithets should be legitimately (in accordance with the Rules), effectively (in printed matter made generally available to the scientific community), validly (effectively published and accompanied by a description of the taxon or a reference to a description and certain other requirements) and correctly (the name which must be adopted for a taxon under the Rules) published (Seifert et al. 2010). Pleomorphic fungi should have one nomenclaturally correct name in a particular classification according to Article 59.1, of the International Code of Nomenclature for algae, fungi, and plants (ICN; Melbourne Code), (Wijayawardene et al. 2014c). This has two major consequences:

(1) The correct name is now the earliest published legitimate name; i.e. the principle of priority applies regardless of the sexual stage represented by the name-bearing type.

(2) Names had been introduced for different morphs of a single taxon, those names would, strictly speaking, be either (a) alternative names (and so not validly published, if proposed at the same time), or (b) nomenclaturally superfluous and illegitimate (if proposed for a taxon where one morph already had a legitimate name). In view of the potential disruption this would cause, names in those two categories are ruled as validly published and legitimate - (Art. 59.1).

The absolute identification of fungi is of great practical importance not only in clinical approaches, but also in plant pathology, biodeterioration of materials, biotechnology and environmental studies (Guarro et al. 1999, Jayasiri et al. 2015). Numerous novel species have been described over the last few decades and classification schemes have been revisited. With these ongoing taxonomic revisions, a considerable number of species have received only limited study as classification and nomenclature has mainly been rooted to traditional ways based on morphology, 
host, locality and above all, sticking to type specimens/old names, which are not always easily accessible or may be in poor condition (Talbot 1971, Blackwell 2011). The widespread vague taxonomic concept of naming species based on host is quite erroneous and has resulted in species with few character differences and egregious misidentifications (Jeewon et al 2004, Hibbett et al. 2007). Table 1 provides a snapshot of some of the major genera whereby many species names have been associated with hosts and to date the validity of all these names warrants investigation.

Table 1 Numerical representation of species described based on host and locality within selected genera with name controversies.

\begin{tabular}{|c|c|c|c|}
\hline Genus & $\begin{array}{l}\text { Total } \\
\text { species }\end{array}$ & $\begin{array}{l}\text { Currently accepted } \\
\text { species (remarks) }\end{array}$ & References \\
\hline Anthostomella & 416 & $\begin{array}{l}95 \text { (many species } \\
\text { erroneously classified) }\end{array}$ & $\begin{array}{l}\text { Danaragama et al, } \\
2016\end{array}$ \\
\hline Botryosphaeria & $276 / 284$ & 110 & $\begin{array}{l}\text { Liu et al. 2012, } \\
\text { Phillips et al. } 2013\end{array}$ \\
\hline Camarosporium & Over 500 & $\begin{array}{l}\text { Unknown (comprises a } \\
\text { large number of species } \\
\text { that merit re-examination) }\end{array}$ & $\begin{array}{l}\text { Wijayawardene et al. } \\
2014 \text { b, c }\end{array}$ \\
\hline Colletotrichum & Over 500 & 193 & $\begin{array}{l}\text { Jayawardene et al. } \\
\text { 2016b }\end{array}$ \\
\hline Massarina & 190 & $\begin{array}{l}43 \text { (previously } 53 \text { or more } \\
\text { were described based on } \\
\text { host) }\end{array}$ & Aptroot 1998 \\
\hline Pestalotiopsis & $235 / 232$ & $\begin{array}{l}\text { Unknown (as most of them } \\
\text { have been named after the } \\
\text { host) }\end{array}$ & $\begin{array}{l}\text { Maharachchikumbura } \\
\text { et al. } 2011\end{array}$ \\
\hline Stachybotrys & 128 & 74 (wide host range) & $\begin{array}{l}\text { Wang et al. (2015), } \\
\text { Lombard et al. (2016) }\end{array}$ \\
\hline Phyllachora & Over 1100 & 1502 & $\begin{array}{l}\text { Pearce 1994, Santos et } \\
\text { al. } 2016\end{array}$ \\
\hline
\end{tabular}

Any fungal name that is confused, invalid, or illegitimate or not coexisting with designated type material (a single collection made at one place and time represented as a single specimen in a single institute [listing the collector, date, and collection number] or a permanently metabolically inactive culture or tissue [i.e. frozen, dried, or pickled] or an effectively published illustration) that requires nomenclatural or taxonomic attention is regarded here as an old fungal name (Table 2). For example, many Colletotrichum species have been wrongly named (Hyde at al. 2009) and Jayawardena et al (2016b) have outlined the importance of correctly naming species. Jeewon et al (2004) and Maharachchikumbura et al (2011) assessed taxonomic relationships among Pestalotiopsis and allied genera and concluded that the large number of described species has resulted from introductions based on host association and are probably not good biological species. There is probably an overestimate of species number for many genera, which needs to be reassessed. More importantly, is the validity of those names in those large genera, which also needs to be revisited. Assessment of Phyllachora by Pearce et al. (1999) showed that some of the taxa are of dubious value, because they had been inadequately described and then transferred to Phyllachora without reviewing the type collections which contained no fertile components, doubt on the host plant, or the taxa were synonyms of previously described Phyllachora species. Many old specimens are also in quite poor conditions. Podosordaria mexicana Ellis \& Holw., collected in 1896 on cow dung, is a highly-deteriorated specimen. Others are exhausted by repeated examination e.g. Halosphaeria appendiculata Linder (Barghoorn \& Linder 1944). Similarly, the genus Squamotubera is only known from its short Latin prologue by Hennings (1903) with no illustrations. Table 2 provides other examples in connection to problems with old names. 
Table 2 Particular instances with problems with regards to old fungal names.

\begin{tabular}{|c|c|c|}
\hline Species name & problems with old fungal names & References \\
\hline Botryosphaeria mamane & $\begin{array}{l}\text { No authentic culture and no subsequent } \\
\text { collections from the type locality }\end{array}$ & Crous et al. 2006 \\
\hline Phyllachora. trivialis & $\begin{array}{l}\text { Impossible to identify the host from the } \\
\text { fragments of leaves left in the holotype and no } \\
\text { molecular data }\end{array}$ & Pearce et al. 1999 \\
\hline Phyllachora asclepiadis & $\begin{array}{l}\text { Inadequacy of their original descriptions, } \\
\text { and lack of phyllachoraceous fertile structures }\end{array}$ & Pearce et al. 1999 \\
\hline Cercospora gay-lussaci & $\begin{array}{l}\text { No fungus corresponding to Spegazzini's and } \\
\text { Chupp's descriptions been found }\end{array}$ & Braun et al. 2000 \\
\hline Microascus dimonatus & $\begin{array}{l}\text { Only ex-type culture of this fungus exists in } \\
\text { (CMPG 1274) but not available for examination }\end{array}$ & $\begin{array}{l}\text { Sandoval-Denis et } \\
\text { al. } 2016\end{array}$ \\
\hline Scopulariopsis maduramycosis & $\begin{array}{l}\text { No holotype information and was published } \\
\text { with inadequate descriptions }\end{array}$ & $\begin{array}{l}\text { Sandoval-Denis et } \\
\text { al. } 2016\end{array}$ \\
\hline Podosordaria mexicana & $\begin{array}{l}\text { Specimen collected in } 1896 \text { on cow dung is } \\
\text { highly deteriorated, while others are exhausted } \\
\text { by repeated examination }\end{array}$ & $\begin{array}{l}\text { Daranagama et al. } \\
2016\end{array}$ \\
\hline
\end{tabular}

In this paper, we present controversies associated with old fungal names furnished with relevant instances, case studies and possible remedies.

\section{Problems with old protologues}

In the past, it was extremely difficult to introduce new fungal taxa, as mycologists used only a small number of morphological characters to differentiate fungi and these were often limited and therefore many probable novel species have been left undiscovered (Frisvad 2015). In addition potential mycologists with appropriate expertise were scarce. Every description of a fungal species is unique hence; morphological, physiological, ecological, and molecular polygenetic descriptions and illustrations differ from one taxonomic group to another. These discrepancies have made it ever more difficult to set formal standards for the description and illustration of species (Seifert et al. 2010). Phylogenetic approaches, incorporation of molecular biological techniques, particularly the analysis of DNA nucleotide sequences, information on biochemistry, enzyme production, metabolite profiles, physiological factors, growth rate, pathogenicity, and mating tests have greatly influenced and resulted in significant changes in the traditional concepts of fungal systematics (Guarro et al. 1999, Abang et al. 2009, Taylor et al. 2000, Vellinga et al. 2015). The early publications on Neurospora describe four species, three with eight spores per ascus and one with only four and the species boundaries were dependent on spore dimensions (Shear \& Dodge 1927, Tai 1935), which were overlapping (Perkins et al. 1976). Therefore, subsequent studies of Perkins \& Turner (1988) and Turner et al. (2001), relied on mating tests to pairs of tester strains to assign individuals to species instead of relying only on morphology. Colletotrichum kahawae was distinguished from $C$. gloeosporioides based on physiological and biochemical characters (Correll et al. 2000, Hyde et al. 2009). Equally, relative growth rates and the production of secondary metabolites on defined media under controlled conditions are valuable in defining species boundaries within complex genera such as Aspergillus, Penicillium, and Colletotrichum (Frisvad et al. 2007, Samson et al. 2007, Cai et al. 2009).

Most of morphological descriptions by Spegazzini, Petrak and Saccardo lack information currently used today on characters essential for interpretation of taxa, and illustrations are quite poor due to conventional means of photography available at that time. For instance, Spegazzini described numerous new genera and species of all fungal groups, including 71 species of Cercospora and Cercosporina (Farr 1973), but most of them lack appropriate illustrations and descriptions.

In this modern era, morphological descriptions have advanced due to greatly improved microscopes, which allow more reliable phenotypic characterization. Updated computer technology 
has also enabled the use of effective statistical packages, development of identification keys, automated image analysers, electronic particle sizing and fractal geometry and these have helped to better understand fungal morphology of old names.

Most mycological journals now publish articles including new species online and deposit printed copies in recognised national libraries. Type material, with a unique accession number should be preserved in a public herbarium (Holmgren et al. 1990) and made available to interested scientists in an online repository if possible to facilitate species identification of the type specimen. Maharachchikumbura et al. $(2015,2016)$ and Hyde et al. (2013) are good examples of revisions at higher taxonomic levels published with sufficient taxonomic details including revision of classification schemes and appropriate accession details to facilitate future species identification. These should serve as good examples in fungal taxonomic studies.

\section{Associated problems with loaning fungal type material}

It is desirable to re-examine the name-bearing type material to confirm whether the previously named taxon is similar or different to the one recently collected, or when revising genera or families, or preparing monographs. It is estimated that about $70 \%$ of the herbarium taxonomic diversity is not yet represented in GenBank (Brock et al. 2008), hence, it is ideal to re-examine related type material when introducing fungal species or resolving taxonomic confusions. This is likely to be of much greater importance with fungi to help define the original concept of taxa, especially at lower taxonomic ranks and lead to better identification that would provide more reliable fungal estimates and classification.

The complications of locating and loaning type materials need a special mention as the majority of name controversies are accompanied by deficiencies of type details. The limitations associated with locating herbaria include, lack of reference data due to loss or damage or not being available in the public domain. For instance, locating type material of Hypocopra merdaria (Fr.) J. Kickx f., Fl. (1867) is/was a problem. In early studies, some authors did not designate any type and some did not even state the location where they deposited their collections accurately (e.g type material of Cercospora cordylines Speg., Rev. Mus. La Plata 15: 45 (1908) could not be located at LPS and is possibly not preserved in this herbarium (Braun 2000). Sutherland (1915, 1916), did not deposit type material of many marine fungi, e.g. Cercospora salina Suth. These situations pose serious difficulties to connect existing species to old names and personal visits to the possible holding institutions to counter check any old names and their types are prohibitively expensive (Hawksworth 2014). In 1998, KD Hyde visited the herbarium of Cribb at the University of Queensland, which was in his office. He had only kept a few poorly labelled slides that had become dried and displayed very few useful characters.

It is now no longer possible to loan Fries (e.g holotype of Phyllachora impressa), Persoon (e.g type of Polystigma rubrum), Saccardo (e.g type of Anthostomella limitata) and Spegazzini herbarium material (e.g holotype of Cercospora smilacina). PAD will send images of the types, but this is close to useless when dealing with microfungi. There are some records with ruined or damaged fungal materials. For example, the holotype of Hypocreodendron sanguineum Henn. (1897) deposited by Hennings was destroyed by fire and specimens of Möller (soaked in ethanol) that survived 100 years were kept in a fireproof cupboard at herbarium B but were destroyed during World War 2. However, some duplicates of Möller specimens have survived in S and FH, which frequently constitute only fragmentary, immature, and/or depauperate stromata, have been available for post-war revisions (Stadler et al. 2008a). Most of Spegazzini's collections are scanty; often in poor condition and impossible to use as specimens that interpret particular species (Braun 2000).

The holotype of Calceomyces lacunosus Udagawa \& S. Ueda should be in TRTC but the material is now missing from the herbarium. Herbaria that lack online databases such as IFDR, PC and YAM are difficult to use when seeking specimens. For some herbaria with online databases, appropriate information or guidelines are unavailable to facilitate loaning of type materials. The absence of any contact details of herbaria or curators and the unresponsiveness of some (e.g. Herbarium Hamburg) are additional inconveniences when requesting types. Several herbaria from 
India will not send types out of the country. Several earlier herbaria have been transferred to another place with the same names, or different names, for instance in 2010, the former IMI herbarium was merged with that of the Royal Botanic Gardens, Kew.

Some herbaria have policies that restrict loaning of any type material especially under circumstances where there are few fruiting structures on hosts, extremely fragile materials, when collectors have deposited little material of specimens, when they exist as exsiccatae, or in cases where specimens are seldom collected. Type material of for example, Mastigosporium album Riess (1863) is in an exsiccatum in bound book form, which cannot be loaned from National Herbarium Netherlands (HAL). BILAS herbarium, which comprises about 8,000 specimens of lichens and lichenicolous fungi, does not permit loaning of holotype materials. Herbaria with collections from the early $19^{\text {th }}$ century and before, will no longer lend material under any circumstances, generally as a result of unfortunate experiences in the past (Hawksworth 2014). RO herbarium has restricted loaning type, historical and environmentally rare specimens. Spegazzini maintained most of his collections as a personal herbarium (LPS) and it is not currently available for loan. Furthermore, some restrictions might be a result of loss or damage to type material in postal systems, or destroyed due to quarantine regulations. For instance, type material requested from Poland and Russia to be studied in the UK failed to reach their destination, possibly due to strict quarantine regulations (Hawksworth 2014).

Another limiting factor of studying type arises when few/single or hard or degraded ascomata are present on specimens and not suitable for morphological observations. For example, the holotype of Sphaerodes episphaerium (W. Phillips \& Plowr.) Clem. lacks fruiting structures for appropriate morphological observations (Fig. 1). Engleromyces goetzei Henn., collected from Zambia in 1899 and deposited in B is now hard and degraded and not suitable for morphological observation (Daranagama et al. 2016). Another major problem would be that it is very unlikely that the stromata would yield good quality DNA.

\section{Comparing types with modern collections and DNA sequencing of old fungal material - are they feasible?}

In the past, types were described solely on morphological characters, which can now generally be considered as being rather subjective, because of the lack of DNA sequence data. When defining new taxa, some authors might favour length/width ratios, while others would rely on spore shape or colour when defining new species. Today, when we compare these types with modern collections, some problems arise. If the types lack sequence data, it becomes very difficult to refer it to an appropriate taxonomic rank, for example genera within Elsinoaceae and Myriangiaceae have not yet been resolved based on DNA sequence data (Jayawardena et al. 2014). Once we acquire a fresh collection, we should be able to identify it to family or genus level with sequence data, however giving an exact scientific name is difficult because the type species probably has not been sequenced. In this case comparing types with modern collections is difficult.

New fungal taxa are continuously being proposed based on DNA sequence data, often without knowing if these have been previously described based on morphology. However, amplifying and sequencing DNA from old specimens depends on its age, amount of materials and storage conditions. Sometimes, only short DNA regions (especially from rDNA genes) are successfully amplified and sequenced from old specimens. To our knowledge, the oldest specimen from which ITS sequences could be obtained is Agaricus cossus, the basionym of Hygrophorus cossus, in the fungarium of the Royal Botanic Gardens Kew (K), which had been collected in 1794 (Larsson \& Jacobsson 2004). Recently, Landeros et al. (2015) successfully sequenced partial $28 \mathrm{~S}$ rDNA from a herbarium specimen of Helvella fusca, which had been collected 118 years earlier in 1898 (Landeros et al. 2015). The percentage success with microfungi might be very minimal and highly destructive. In addition, with so many fungal species yet to be described and discovered, we wonder whether it is really worth investing to generate sequence data from old fungal material. 


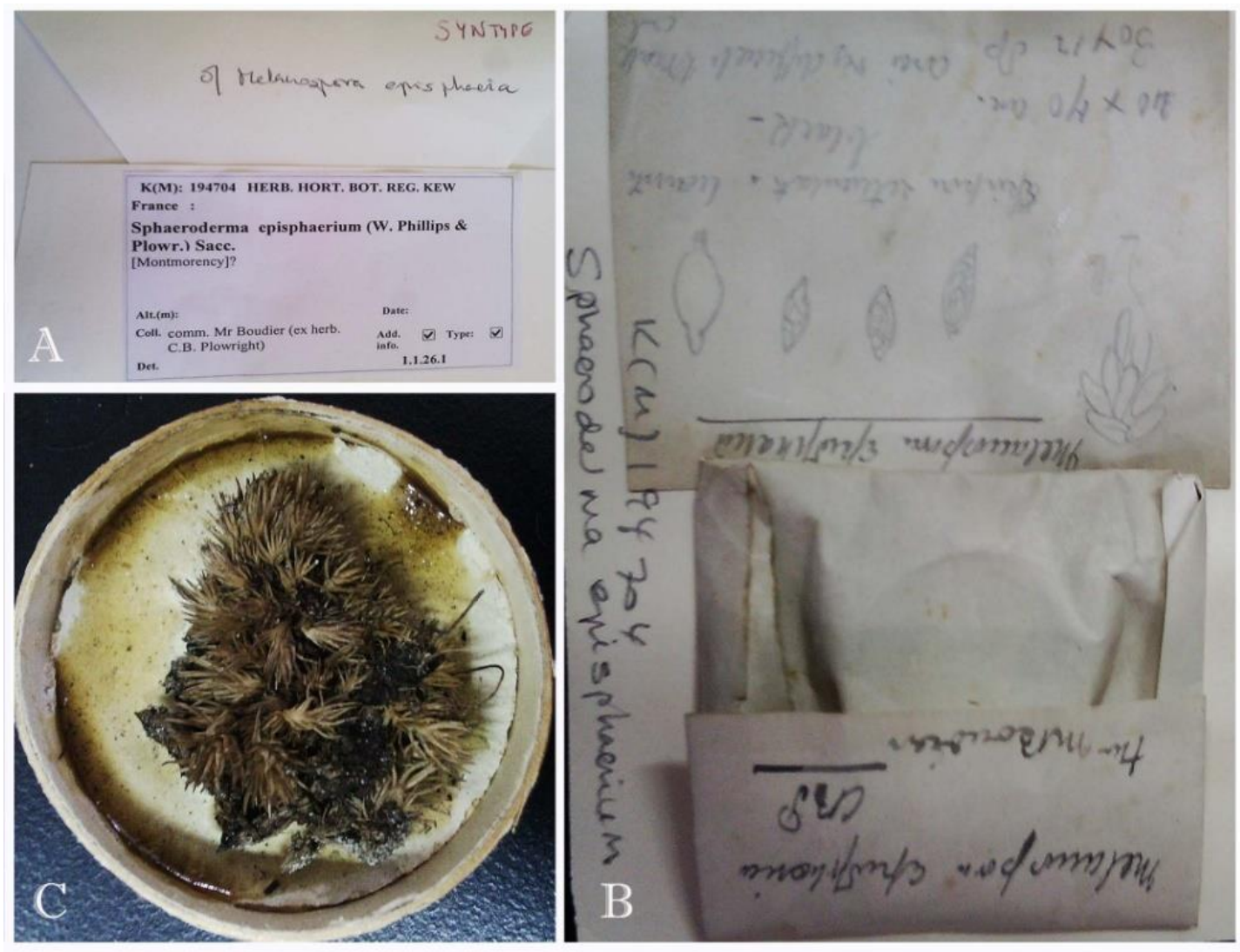

Fig. 1 - Sphaerodes episphaerium (IMI 208400, holotype). A-C Herbarium material and illustrations.

\section{Comparing new species with old names - what is expected and why it is flawed}

Our traditional Linnaean classification system relied heavily on morphology, but for the last few decades, taxonomists have relied upon morphology as well as DNA sequence data to name species and compare them with extant ones. In cases where the genus is monotypic, a comparison with the type species is essential. As mentioned before, loaning and verification of type specimens is not always feasible for various reasons. When describing new species, and giving names to them, mycologists are governed by the ICN. The latter also provides a platform to eliminate any bias or taxonomic controversies where multiple names are used for the same species. However, application of "one species one name" is still in its infancy in mycology, primarily because many fungi are still only known in either their sexual or asexual state. Under most circumstances, when describing new species, mycologists recover and describe mostly only one state. It would be extremely difficult not to accept the other state if this has been described somewhere else with a different name (e,g describing the asexual state for an existing sexual fungi). This nomenclatural problem is, however, being partially overcome nowadays with DNA sequence analyses, but this largely depends upon whether taxonomists have deposited DNA sequence data for the other state in major databases or whether there is enough number and reliable DNA sequences available for comparison. It has been shown on numerous occasions that many type/reference materials are not in appropriate conditions and DNA sequence data are not available to allow proper morphological comparisons with new species. This is even more problematic when i) the genus is monotypic; ii) type specimens have been collected many decades before; iii) habitats where previous materials have been collected have been destroyed and therefore recollection and re-examination is impossible.

When publishing new species or revisiting classification schemes of heterogeneous genera, it is now common practice to include phylogenetic data. The ITS rDNA gene sequence has been the major DNA barcode that serves the primary basis for assigning a taxon to a taxonomic rank and ultimately provides evidence of species novelty. With respect to large genera with numerous 
cryptic species, it is virtually impossible to re-examine all species. For many genera, for example in Pestalotiopsis, there have been many species described in Guba's (1961) monograph and Nag Raj (1993) with no DNA sequence data and therefore strong reliance on old names is not practical.

The ICN has laid down the general prerequisites on valid publication of names (Article 38) and Jeewon \& Hyde (2016) have proposed general recommendations pertaining to the establishment of new fungal species. Although mycologists rely heavily on morphological characters as has been practice in the description and erection of new taxa, we have made great headway in terms of relying on DNA sequence data. We have observed over the last decades that DNA-based evidence has been predominant and given much importance when diagnosing new species, even under circumstances when morphological differences are not clear. So, are we heading towards a DNA-based method of erecting new species? If yes, then possibly in the near future only a fragment (or fragments) of DNA sequences will suffice to name a species! This makes us wonder about the fate of all those old names and their taxonomic details deposited in herbariums? Will they become obsolete?

\section{Case studies pertaining to the use of old names}

\section{Anthostomella}

Anthostomella is a polyphyletic genus of Xylariaceae and only a handful of species have cultures and even fewer species have DNA sequence data. The monograph of Lu \& Hyde (2000), following an extensive study of herbarium materials worldwide, provided the first comprehensive account of the genus and a lectotype. However, there are no available type-derived cultures of $A$. tomicoides. Hence recent phylogenetic studies on Anthostomella have relied on a living culture of A. formosa, which is morphologically somewhat similar to the type, for a taxonomic rearrangement of Anthostomella sensu stricto (Daranagama et al. 2015, 2016).

Index Fungorum lists 416 names, while MycoBank lists 437 names presumably introduced based on hosts or habitats. Most of these names are based on poorly illustrated protologues based on very few characters, which certainly cannot be used in classification. Previous taxonomic revision resulted in synonymy, transfer and exclusion of many taxa ( $\mathrm{u} \mathrm{\&} \mathrm{Hyde} \mathrm{2000),}$ Danaragama et al. 2016). To date, there are about 65 Anthostomella species which are considered as doubtful since they lack any herbarium material for observation and comparison. Therefore, the problem is that if we rely on old names, it would be highly probable there would be further misidentification of species.

\section{Botryosphaeriales}

A landmark in the taxonomic history of Botryosphaeriaceae was when Slippers et al. (2004) proposed a neotype and epitype for Botryosphaeria dothidea, thus placing the type species of the genus and the type genus of the family on a stable base. It also established a solid base for molecular phylogenetic treatments of the genera and species in the family. While morphology is, to a certain extent, useful in distinguishing genera in the Botryosphaeriaceae, taxonomy of the family relies heavily on DNA-based phylogenetic analyses (Yang et al. 2016). However, this trend has introduced an additional problem of deciding on criteria that define species boundaries. Thus, we have reached a point where there is a danger of introducing new species names for what amounts to individual lineages within a species. The examples we give below are not a complete treatment of all genera since we refer to only those for which we have first-hand experience.

\section{Botryosphaeria}

Of the 276 names for Botryosphaeria listed in Index Fungorum and 284 in MycoBank, some have been transferred to Neofusicoccum, while others have been transferred to other genera. When Crous et al. (2006) showed that Botryosphaeria sensu lato comprises ten phylogenetic lineages, only two species (B. dothidea and B. corticis) were retained in Botryosphaeria. With a suitable neotype, epitype and associated culture designated, $B$. dothidea had become stable. An 
epitype for $B$. corticis was also proposed to stabilise that name. Of the remaining species introduced since Slippers et al. (2004), all are new names and none of the old names had been considered. In our view this was a sensible decision considering that the sexual state is uncommon, morphology of the sexual and asexual morphs vary little between species. We would even go as far to suggest that there is no point in even attempting to resurrect any of the old Botryosphaeria names.

\section{Diplodia}

Most of the earlier species names in Diplodia were introduced based on host association resulting in many species. Since host association is considered to be uninformative for the majority of species, many of these names would be expected to be synonyms. Around 2001, Alan Philips (pers. comm.), optimistically decided to re-examine all of the old names by studying the holotypes. Very soon he realised this was going to be an impossible task. The first problem was to locate the types and when located the herbaria either could not find the specimens or they no longer loaned specimens. Of the types he did manage to look at, some were in poor condition, others were a mixture of morphological species. The final frustration was that of the specimens he examined, only three basic conidial morphologies could be distinguished with any degree of reliability; aseptate and hyaline, aseptate and coloured, 1-septate and coloured. Since we had already established that conidia within a single phylogenetic species could be aseptate and hyaline, becoming 1-septate and coloured at some later stage, it was clear that the herbarium specimens were of little value in separating these old names or determining synonyms. Nevertheless, some minor distinguishing features that possibly defined a few key species were found. The old specimens were therefore useful to tie-down the type species (Diplodia mutila) and to eventually propose an epitype (Alves et al. 2014) that has provided a solid base for the genus. On the other hand, there is always some doubt about whether the correct specimen for the epitype has been chosen. However, this can be considered from another perspective. After examining many cultures and many herbarium specimens, it was possible to move forward and propose an epitype that was typical of the interpretation of a typical Diplodia and that would provide the basis for future studies in the genus.

Over the years some of the old names have been resurrected where possible. For example, it was suspected that Diplodia malorum had a preference for Rosaceae hosts. When it was shown that isolates from apple were morphologically and phylogenetically distinct from other Diplodia species on this host, the old name of D. malorum was resurrected (Phillips et al. 2012). It was relatively simple to locate and loan the holotype of $D$. malorum, and propose a specimen that was considered to represent this species. Other old names that have been resurrected are Diplodia fraxini (Alves et al. 2014) and D. cupressi (Alves et al. 2006).

Yet another case is that of Diplodia seriata. When Crous et al. (2006) split up Botryosphaeria, B. obtusa was orphaned. It was not a species in Botryosphaeria and it did not have a name in Diplodia, where it resides phylogenetically. The oldest name in Diplodia that agreed with the morphology of $B$. obtusa was therefore searched, a holotype located and an epitype and associated culture was chosen.

In all the examples above there will always be some doubt as to whether the "correct" epitype specimen for the old name was chosen. However, because plant pathologists and mycologists are happy to have stable names to work with, we must move forward. Taxonomists also have a basis on which they can build and develop phylogenies. The purists are probably unhappy with the way we chose the epitypes, but nobody has yet complained.

\section{Dothiorella}

Another genus with a troubled past is Dothiorella. Crous \& Palm (1999) reduced Dothiorella to synonymy under Diplodia. Phillips et al. (2005) re-examined the holotype of Dothiorella pyrenophora and determined that certain morphological features are unique and that this species warrants its own genus and thus re-instated Dothiorella. However, morphology of the 
currently accepted species for which DNA data are available varies so little between species that we can agree that morphology is not a useful character at species level. Thus, it would be futile to attempt to re-examine holotypes of any of these species and thus all of the 400 or so old names can be safely ignored.

\section{Ampelomyces}

The species taxonomy of the mycophylic genus Ampelomyces, which is common and widespread on powdery mildews, is a tough challenge. Eighteen Ampelomyces species have been described and all were reduced to synonymy under A. quisqualis, the type species. Pintye et al. (2012) found that $A$. quisqualis sensu lato is composed of several cryptic species reflected in some clear clades in phylogenetic trees with sequence differences beyond the limits of species. These cryptic species are, however, morphologically indistinguishable and their host ranges are totally overlapping. The challenge in an ongoing project, will be to clarify the nomenclature and taxonomy of species. On one hand, 18 species names are available, but on the other hand, there is no possibility to resolve species and reallocate others based only on morphology. The only way to overcome this frustrating dilemma and to find a solution for the taxonomy on species, lies in the epitypification of appropriate names with new collections, including ex-epitype cultures and retrieved sequence data. Ignoring and omitting all old names would be the only alternative, This would, however, lead to the introduction of several new species names, although these might be permanently endangered since one of the older names could at any time be linked with each of these species and reinstated as older name via epitypification. The interpretations and character determinations of names by epitypifications could be considered to be arbitrary. Corresponding proposals are, however, quite comparable with neotypifications and proposals to reject names or to protect names, sometimes with conserved types which alter the circumscriptions of genera.

\section{Cercosporioid fungi}

We are confronted with many problems in the application of names of cercosporoid fungi, above all within Cercospora names, in particular as far as names belonging to the Cercospora apii complex are concerned. Although most cercosporoid fungi are plant-pathogenic and considered to be host-specific, $C$. apii sensu lato turned out to be a complicated complex of host-specific as well as plurivorous species with different, often wide and overlapping host ranges (Groenewald et al. 2013). In plant-inhabiting, above all plant-pathogenic species, the hosts provide the most important indications, besides geographical details (localities), to find appropriate epitype material. This is the way that we began to disentangle the complicated problems around species of the $C$. apii complex. In a first step, type specimens (holo-, lecto-, neotypes) of species assigned to Cercospora were traced and re-examined (Crous \& Braun 2003). In a second step, whenever available and possible, new collections suitable as epitypes have been searched, i.e. on type hosts from areas sufficiently close to the type locations, which could be used as source for ex-epitype cultures as a basis for molecular sequence analyses. For clades representing species with wide host ranges, the oldest involved species name from the $C$. apii complex has been taken and applied to name this clade (species), either by establishing names through epitypification or by using these names tentatively until appropriate epitype material becomes available. However, a key task to resolve the $C$. apii complex was, of course, the determination of the application of $C$. apii s. str., which is also the type of the genus Cercospora (Braun \& Crous 2016), by lecto- and epitypification, including an exepitype culture and sequence data for the phylogenetic characterization. Attempts to sequence old type material have not been made and it is not worth the effort as it usually has no prospect of success. The conclusions and epitypifications are based on morphological comparisons, which is of course subjective. However, for such cases, the tool "epitypification" has been implemented following the Code and has allowed us to move forward in understanding the $C$. apii complex. Cladosporium is another case in point, although, in contrast to Cercospora, are complexes of numerous cryptic species (Bensch et al. 2012). Clear typifications, including epitypes, genetic characterizations and unequivocal circumscriptions of these species were also the crux of all 
attempts to disentangle the taxonomy of these species complexes. The monograph of Cladosporium published by Bensch et al. (2012) is a good example for a successful solution of a large, complex, taxonomically difficult genus.

\section{Colletotrichum}

Colletotrichum is a well-known phyto-pathogen, as well as an endophyte, a saprobe and a human pathogen (Promputtha et al 2007, Hyde et al. 2009). Traditionally, species names were based on host-association. This taxonomic activity has been driven by the assumption that Colletotrichum species are strongly host-specific. Therefore, many of the species described with regards to host association are not good species and many are likely to be synonyms (Weir et al. 2012). Based on morphological characteristics with little or no emphasis on pathological features, von Arx monographed the genus, which led to the reduction of the accepted number of species. In his effort, many taxa were re-evaluated based on descriptions from literature, rather than evaluation of type specimens. Jayawardena et al. (2016a) outlined the importance of correctly naming Colletotrichum species. Cannon et al. (2012) accepted 118 species, Hyde et al. (2014) accepted 161 species and Jayawardena et al. (2016b) list 190 accepted species. Index Fungorum (2016) lists 820 epithets under Colletotrichum, but only less than 200 names are currently accepted.

Hyde et al. (2009) provided a comprehensive overview of this genus with 66 names currently used and 19 doubtful names which reflected the increasing reliance on molecular methods in species identification. In this paper, pre-1980 records were excluded and Sutton (1980) was used as the starting point for names in the genus. Also, the names from older checklists that are rarely used were treated as uncertain. All the studies conducted after 2009 were entirely based on Hyde et al. (2009). Rarely used species names such as $C$. metake and $C$. hsienjenchang have been sequenced to validate their placement in the genus (Jayawardena et al. 2016b). The majority of these species are cryptic species with few distinct characters. Therefore, the use of old species named in literature might be misinterpretations or synonymies. If the taxonomists had insisted on using all older names, the complexity of this genus would still not have been resolved.

Some scientific communities like to use the old names for convenience. For example, species of gloeosporioides are important pathogens causing fruit rots and have earlier been given the name C. gloeosporioides. Even though, they could have been identified as different species, plant pathologists still prefer to call them as $C$. gloeosporioides instead of their current scientific name. Once, a new species is identified in this genus, it is better to consider whether this taxon has been previously identified on a different host. Many of the descriptions have been included with detailed drawings, and the type materials have been deposited in herbaria. As the majority of type specimens are lost or not in a good state, it has become problematic to sequence them. However, older species names that have been related to their type materials have been re-described among species such as $C$. circinans, $C$ curcumae, $C$. dematium, $C$. orbiculare and $C$. lineola (Damm et al. 2009, 2013). Some of the species have been epitypified or neotypified. Colletotrichum camilliae, $C$. gloeosporioides, C. orbiculare and C. nigrum provide good examples of this (Cannon et al. 2008, Damm et al. 2013, Liu et al. 2013, 2015).

Today, we rarely consider the old Colletotrichum names and if we did consider them it would probably be futile as we may have introduced species under a new name now or it may fall under an existing accepted species. Therefore, we can say that the genus Colletotrichum provides a good example for moving forward with the new names and not using old names that cannot be resolved with both morphology and phylogenetic evidence. Colletotrichum taxonomy is still ambiguous and previous researchers have already identified potential problems with putative old names (Hyde et al. 2009, Cannon et al. 2012) and misidentifications based on morphs and DNA sequence data are also very common (Cannon et al. 2012). Therefore, a more general solution would be to move forward with new names. Old names can still be used if the need arises, provided they are made available without constraints. 


\section{Diaporthe}

Species in both Diaporthe and Phomopsis exhibit different lifestyles (Castlebury et al. 2002, Dissanayake et al. 2015) and most species have been described based on their host-specificity, but recent DNA sequences based studies have shown that only few species are host-specific, while many others have a broad host range (Hyde et al. 2014). Many names for sexual and asexual morphs of Diaporthe/Phomopsis have been used in the earlier literature and nearly 1000 names have been described in each genus (Index Fungorum 2016). Defining the precise names of species of Diaporthe is problematic since names in both genera must be taken into account. Recently, Rossman et al. (2015) recommended the name Diaporthe over Phomopsis, resolving much taxonomic confusion of this pathogen group, but both names still exist in the old literature (Udayanga et al. 2011) and are still used by some plant pathologists (Gao et al. 2016, Mctavish et al. 2016).

Using old names is nearly impossible for Diaporthe, due to the lack of distinctive morphological characteristics. Wehmeyer (1933) synonymized many names under each of the species in his monograph. Many names previously documented in Phomopsis already have an older epithet in Diaporthe (Rossman et al. 2015). As an example, D. ampelina (= Phomopsis viticola, D. neoviticola), Udayanga et al. (2012) proposed $D$. neoviticola as a nom. nov. for $P$. viticola. As this name is superfluous, Gomes et al. (2013) suggested the older epithet ampelina has precedence and should be adopted. When it comes to the type species of Diaporthe, D. eres, some names related to this species are older (Udayanga et al. 2014). Recently, D. eres, has been carefully demarcated (Udayanga et al. 2014) and this name is preserved against 21 previous doubtful names (Rossman et al. 2014). Rossman et al. (2015) transferred a number of most important old names and some recently described species from Phomopsis to Diaporthe.

Phomopsis vitimegaspora Kuo \& Leu was identified as associated with dead arm disease of grapevines in Taiwan (Kuo and Liu 1998). The sexual morph was later recognized from Kyushu, Japan with the name Diaporthe kyusuensis Kajitani \& Kanematsu based on ITS sequence similarities (Kajitani \& Kanematsu 2000). Thus, the same species has two completely different names. Since this species has not yet been epitypified, problems arise when assigning new isolates to these taxa. In this case, there is not much DNA based evidence to resolve modern collections with old data. Several contemporary studies have epitypified significant pathogens in Diaporthe, providing clarification of the usage of old names and species boundaries within the genus (Castlebury et al. 2003, van Niekerk et al. 2005, Rensburg et al. 2006, Diogo et al. 2010, Udayanga et al. 2012, Gomes et al. 2013).

\section{Lophiostomataceae}

"Recently several species in Massarina and Leptosphaeria have been described, but can we be sure if they are truly new and whether reference to old names has been taken into account?" Taxonomic relationships within the Lophiostomataceae have been revisited (Hirayama \& Tanaka 2011, Hyde et al. 2013, Thambugala et al. 2015) and recent DNA based phylogenies reported that a considerable number of Massarina, Leptosphaeria, Pleospora, or Trematosphaeria-like species grouped in Lophiostomataceae (Liu et al. 2015, Thambugala et al. 2015, Li et al. 2016). Sometimes, it is difficult to treat those species in Lophiostomataceae based only on morphological characters. Only a few species have sequence data from type species or reliable sources. Therefore, before describing a novel taxon in Lophiostomataceae it is important to make sure whether it is new. However, this is not always practicable as holotypes of many species are not available for study or are in poor condition. There are numerous epithets of Massarina (177), Leptosphaeria (1662), Pleospora (1081) and Trematosphaeria (202) listed in Index Fungorum (2016), but most of them do not have DNA sequence data. Thus, a new collection may have been previously described, but to establish this one would need to re-examine the many hundreds of epithet types. This exercise would be extremely time consuming (years) and several of the types may be at herbaria that do not loan material, may be lost, or may be in poor condition. Therefore, to move forward 
expediently, it is more convenient to describe any new species or genera with molecular data. Later, if someone has the time, desire and funding to look at all the old herbaria material, they can do this and designate epitypes and synonymize any of the recently described taxa. Thus, progress will not be held up. Finally, even if studies find a 100 to 200 -year-old specimen that looks similar to the new species or genus, any identification will be subjective, since it is very unlikely that sequence data could be obtained from such old herbarium material.

\section{Pestalotiopsis}

Most of the described Pestalotiopsis species were established based on host association (Maharachchikumbura et al. 2011). Recent molecular data have shown that conidial characters can be used to discriminate species and host association is less informative (Jeewon et al, 2003, 2004, Maharachchikumbura et al. 2011, 2012, 2014). Therefore, many of the traditional host-based taxa are probably not good species. Guba (1961), Steyaert (1949, 1953a, b, 1955, 1956, 1961) and most other workers primarily used dried herbarium material and conidial characters from cultures to characterise and describe new taxa. Sutton (1980) pointed out that when species of Pestalotiopsis were grown in artificial culture, there are variability in conidial morphology as well as formation of aberrant conidia. Therefore, identification of species from culture and the application of names based on herbarium taxonomy present a confusing situation. For this reason, naming of species is difficult and highly subjective and many sequences of Pestalotiopsis deposited in GenBank are likely to be wrongly named (Maharachchikumbura et al. 2011). Guba's (1961) taxonomic arrangement based on pigmentation has not been supported by DNA sequence data (Maharachchikumbura et al. 2011, 2012, 2014, 2016). Thus, most of these described species are likely to be synonyms. There are numerous cryptic species, very few distinct species and therefore, use of dried material and old species names used in literature can lead to misinterpretations or synonyms of species with wide host ranges (Maharachchikumbura et al. 2011, 2014). One might argue that we do not need to consider the old literature and names. Many existing taxa have poor diagnoses, inadequate illustrations, and lack cultures and DNA sequence data. Under such circumstances, taxonomists would be wise to ignore most of the old species names and types and update taxonomic concepts based on fresh collections with DNA sequence data.

\section{Powdery mildews}

Another example refers to the asexual powdery mildew genus, Oidium and its allies, whose taxonomy has been debated and classification revised especially with regard to types and naming of species (Fries 1832, Paul \& Kapoor, 1985, Cook et al. 1997, Braun \& Cook, 2012, Braun 2013). Oidium erysiphoides (Fries 1832) was also a dubious name, i.e. used in a very wide sense for all kinds of asexual powdery mildews, which was definitely in agreement with the original intensions of Fries (1832). Type material of $O$. erysiphoides is not preserved in herb. Fries (L). In the protologue, Fries (1832) also cited "Farinaria seminaria Sowerb., t 360, Fig. 1". However, the description of Farinaria seminaria Sowerb. (Coloured Figures of English Fungi 3: 148, 1803), described on Salix sp., and his illustration are quite unclear, doubtful and could also belong to uredosori of a rust fungus. Fries (1.c.) only cited Fig. 1 under $O$. erysiphoides, but excluded Figs 23 , suggesting his uncertainty about this taxon and plate. Therefore, Sowerby's plate was not suitable for typification purposes. In order to clarify the application of Oidium erysiphoides and thereby Euoidium, Braun \& Cook (2012) neotypified this species name with German anamorph material of Golovinomyces biocellatus on Lycopus europaeus making Euoidium a heterotypic synonym of Golovinomyces. This decision was reasonable since Fries (1832) cited in the protologue "in foliis herbarum, praecipue Labiatarum, vivis autumo " (on leaves of herbs, mainly of the Laminaceae, in autumn ...).

\section{Practical taxonomic solutions and recommendations to old names}

It is important to consider older names when a new species is described. However, because of the paucity of taxonomic information and the unavailability of types, it is often better to 
designate epitypes or neotypes. This has been recent common practice and has clarified taxonomic ambiguity, especially among enigmatic species. The designation of reference specimens, which can later be confirmed and possibly designated as neotypes or epitypes in future studies is also important (Ariyawansa et al. 2014). In some cases, type herbarium material is not available for a species for examination. Types may have been lost or the material (fungal structures) may be depauperate. In these cases it is recommended to designate a neotype. A neotype "is a specimen or illustration selected to serve as nomenclatural type if no original material is extant or as long as it is missing" (Art. 9.7; Melbourne Code; ICN; McNeill et al. 2012). When a modern epitype or neotype is designated, it should incorporate DNA based phylogeny, which is crucial in modern studies.

An epitype "is a specimen or illustration selected to serve as an interpretative type when the holotype, lectotype, or previously designated neotype, or all original material associated with a validly published name, cannot be identified for the purpose of the precise application of the name to a taxon" (Art. 9.8; Melbourne Code; ICN; McNeill et al. 2012). However, lack of sequence data was not considered as an acceptable reason for designating an epitype by current ICN rules, until the material is not "demonstrably ambiguous" and can be correctly identified (Melbourne Code; ICN; McNeill et al. 2012). As argued by Jørgensen (2014), prior to the designation of an epitype with molecular data, it is required to attempt to recover DNA from the type material and fail. This is impractical either when the material is too old to obtain DNA or when the herbarium does not allow DNA to be extracted from specimens. Hawksworth (2014) therefore suggested to delete the phrase "demonstrably ambiguous" from the ICN. Hawksworth (2015) acknowledged that there are cases where molecular data are critical for the correct application of species names and removal of "demonstrably ambiguous" would avoid many of the epitypfications made in recent years being considered invalid (Hawksworth 2015). Besides, designation of a new epitype to interpret an existing epitype is not accepted in the current ICN (McNeill et al. 2012). It is advised to properly locate the specimen and try to obtain DNA sequence data if the original type is in good condition and made available to researchers (Ariyawansa et al. 2014) and thus it would continue to represent the species as the nomenclatural type. However, if DNA is not recoverable from the name-bearing type, and that is vital for identification, it is necessary to designate an epitype that is morphologically identical to the type (Ariyawansa et al. 2014). In cases where materials are inaccessible and cannot be located we suggest to refer to the original description of the type carefully for the morphological characters before designating the sequenced type (e.g. epitypfication of Seimatosporium rosae Corda by Norphanphoun et al. 2015). As per guided in Ariyawansa et al. (2014), epitype material should be deposited in a public repository, and duplicates should to be deposited in another international collection (e.g. BPI, CBS-H, DAOM, HMAS, K, L, M, PDD, S, TNS, UPS, W). The other recommendation is to deposit ex-epitype living cultures in at least two collections (including one public culture collection such as CBS, ICMP, IFO, MUCL, NRRL) and deposit DNA sequence data (including ITS sequence data and other DNA loci in GenBank).

\section{Personal opinions}

In writing this essay it has been extremely hard to arrive at any consensus and with the nature of humans and their personalities we doubt this would ever be possible. In the following section below, various authors therefore present their own experiences and ideas concerning use of old fungal names.

\section{Uwe Braun}

In principle, the question whether we should use old fungal names or not is not at issue. All existing valid old taxon names are relevant in terms of nomenclature and have to be taken into consideration for finding the oldest valid names for certain taxa based on rank and priority. Although often complicated and time-consuming, the search for old type collections and their examinations and interpretations is necessary and belongs to the intrinsic tasks of taxonomists. Ignoring these old names would lead to an undesirable rise of taxonomic names. "The avoidance of 
superfluous introduction of names" is one of the principles of the ICN (International Code of Nomenclature for algae, fungi, and plant, Melbourne Code, Preamble, 1). The objective of the rules of the Code is to put the nomenclature of the past into order and to provide for that of the future (Preamble, 5). This is the spirit of the ICN. In previous times names could be simply rejected by classifying them as dubious or ambiguous names (nomen dubium, nomen ambiguum). These previously often arbitrarily and subjectively applied terms (categories) have no status in the current Code. As an opposite concept, the ICN provides extensive tools to deal with old and unclear names. Typification is the most important instrument in this respect (Art. 7-10). The application of names of taxonomic groups is determined by means of nomenclatural types (ICN, Principle II). Whenever possible, holotypes should be traced and examined (Art. 9.1) or lectotypes of the taxa concerned should be designated (Art. 92, 93, 95, 911, 9.12). If no original material is extent, neotypification is the method of choice (Art. 9.7, 9.11, 9.13, 9.16). However, old types are often scanty or the survived structures are not sufficient for modern interpretations. For such cases, the category epitypification has been implemented in the Code (Art. 9.8), as a powerful tool to overcome complicated taxonomic problems related to names with unclear application. The focus lays on "interpretation" which includes and tolerates a certain extent of subjectivism. Names are just means of understanding to characterize certain taxa.

Type material of old names is often scanty so that necessary adequate (sometimes destructive) examinations are not allowed and not possible. The fructification in other old type collections may be incomplete, immature and does not exhibit structures necessary for modern interpretations. Additional problems may be caused by loan regulations of certain herbaria, like PAD, that may prevent the examination of types, although we often know in such cases that the types are preserved in the herbaria concerned. How can we cope with such problems? The answer is again, epitypification is the tool of choice. According to Art. 9.8, the designation of an epitype is not effective unless the holo-, lecto- or neotype that the epitype supports is explicitly cited. But the Code does not demand the examination of type material and necessary current conditions of type specimens are not defined, i.e. in all cases discussed above it is sufficient to cite existing type material formally, with or without examination, followed by an interpretation of the name concerned based on all other available information from the protologue, including description, illustrations, hosts/substrate and distribution.

The crux of the problem in fungi, above all micromycetes, and other groups of microorganisms is the limited availability of morphological traits and severe problems in interpreting the limited data in the interaction between variability of traits and true differences between taxa. These problems and challenges are however, not confined to old species. The strongly increasing application of molecular methods in fungi reveals a rapidly growing number of cryptic species that can only be identified by means of sequence analyses. In these cases, we are caught between morpho-species comprising morphologically defined names (sensu lato) and genetically defined species. When traditional morphology-based species, whether old or younger, but hitherto not yet genetically characterised, turn out to be complexes of cryptic completely or predominantly genetically defined species, the question always arises which of the genetic taxa (clades) has to be applied to the original old name of the complex (sensu stricto) that has to be split. In such cases, epitypification with new material and/or cultures based on the new collections is the method of choice. In case that all attempts to clarify the application of names by typification fail, maybe due to the lack of appropriate material for a neo- or epitypification, the names concerned can be tentatively classified as "unresolved" and put in corresponding lists of "excluded, doubtful and insufficiently known species" in taxonomic works until true type material or suitable neo- or epitype material will be found. If such names are interpreted and applied in a sense competing with other commonly used names, which could give reasons to confusion and potentially undesired name changes, or if results of typifications lead to unwelcome nomenclatural threats of established, widely used names, the Code provides, as ultima ratio, the tool to make proposals to reject names according to Art. 56. 1-4. 
It can be said that there are no reasons to ignore and omit old names. The Code proves a wide range of tools to clarify the nomenclature and taxonomic application of any existing name. It is strongly recommended to deal with old names carefully, to clarify the identity of the names concerned by using the ample instruments of the Code, above all the provided possibilities to solve such problems by typification. Ignoring eligible old names would be dangerous and a permanent threat to new species introduced for the taxa concerned. Other authors could at any time take up the old name and fix its application in the corresponding sense by epitypification or neotypification if type material is lacking. The only alternative would be to discard all old names that are not linked with DNA data, based on the argument that analyses of old types are too time-consuming and expensive. However, discarding old names would be in serious conflict with the present Code, i.e. a new changed Code would be necessary, but I am in doubt that such changes would have any change to be accepted by the majority of botanists and mycologists. Furthermore, I am convinced that we do not have the right to disqualify the lifetime achievements of generations of mycologists just based on a new technique. Otherwise it could happen that the next generations of mycologists with new and better technical methods will pitifully laugh at our own current work and throw it into the dustbin.

\section{Pedro W. Crous}

Morphology which is not linked to phylogeny, or vice versa is science fiction. If one lives by the above mantra, you in fact have accepted a double-edged sword. Not only do you reject old herbarium specimens as valuable if they are not linked to a DNA barcode or culture, but you also seriously question identifications based on DNA only - especially if these are short ITS barcodes, which in many genera (Alternaria, Calonectria, Cladosporium, Neonectria and Septoria) cannot distinguish taxa at the species level. The naming of species based on environmental data is another issue altogether, and will not be discussed further here, although if based on short ITS sequences, I would be seriously concerned. However, the value of old names, and fungaria, is at question. Through the years, mycologists have named more than 400000 species, but seem to only recognize around 100000 (Hawksworth 2004). Old names thus represent a huge proportion of the supposedly known fungal biodiversity on this planet. Most of these names are linked to inadequate descriptions, not backed up by any illustrations, cultures, or DNA data. If a type specimen is therefore located, it can provide a lot of additional information. Linking this specimen to a DNA barcode however, is quite tricky with microfungi, as the DNA is mostly degenerated or contaminated, meaning that the fungus needs to be recollected. Furthermore, many species that appear morphologically identical are genetically quite distinct, especially in the present era where we acknowledge that most species represent an assemblage of cryptic taxa (Crous \& Groenewald 2005).

Using fungarium specimens to link fresh collections to old names and obtain a good morphological description or illustration and DNA sequence of the species in question is key to future progress. However, if one designates an epitype, we frequently end up at the crossroads with microfungi: are these two organisms really the same, or not? Once an epitype is designated however, the decision should be followed, so one could also argue that to simply designate types when they are morphologically similar, may not be a bad approach. However, to reach the point of designating an epitype, is frequently a long and rocky road. First the holotype needs to be located (many valuable specimens are no longer sent out on loan, or cannot be located), and then one needs to travel to the original country and locality, locate the correct host, and try to find the fungus in question, generate a DNA barcode, and designate an epitype, to properly fix the application of the name. The best way to address this may be to focus on developing new methods to isolate DNA from existing specimens, and thereby fixing DNA barcodes to old names wherever possible. To enable mycologists to do this, however, fungaria should reconsider their guidelines and permissions to allow mycologists more freedom in isolating DNA from old specimens. When considering the investment in time and money that this approach would demand, it may be worthwhile to simply start anew, and properly describe taxa, backed up with DNA data and cultures wherever possible. 


\section{E.B. Gareth Jones}

I may well be the person who instigated this dialogue, for as a supervisor of many $\mathrm{PhD}$ students, I have been concerned for some time when new species in an old genus are described. In a genus like Lophiostoma, where older names have not been sequenced, are we sure our species is really new? I am always reminded by Terence Ingolds' comment when I was equivocating about describing a new Sigmoidea species "publish it because if you are wrong it can be changed quite easily, if do not, then no one will know about your species". As it happens it was new, but sequence data subsequently showed it belonged in a new genus and the assignment to its sexual morph. I believe we have to move with the times and introduce new genera without much concern for old names or types. If someone later discovers an earlier name for the genus it can become a synonym - this is not a problem. As someone working with aquatic fungi, a group only studied in relative recent times, one has had little difficulty with older names. In this field, it has been the lack of deposited type material (Sutherland 1914, 1915, Ingold 19343), and the highly depauperate state of type material (Barghoorn \& Linder 1944) that has been the major problem. In an attempt to delineate a number of marine ascomycetes a wide range methods have been adopted (e.g. scanning and transmission electron microscopy, sequence data) with the consequence that some species have a long synonymy, e.g. Haiyanga salina (Pang et al. 2008). In conclusion, I am of the opinion that we can ignore old names and focus on good documentation of any new taxa, or new combinations we propose, in the knowledge that these can be corrected as new data becomes available. However, with new species based on DNA sequence data, we need to define the degree of relatedness to existing species (Pang 2012).

\section{Kevin D. Hyde}

After years of working with herbarium specimens and probably having examined with my students many more types of ascomycete genera than most other mycologists, I have certainly experienced the many problems associated with old types and thus old names. I still believe that we must attempt to incorporate old names in our publications, especially at the generic level, but when we deal with species I am far less convinced as can be seen with the case studies (Anthostomella, Botryosphaeriaceae, Colletotrichum, Diaporthe) presented in this essay. At the genus level, we should try to use old generic names and should examine the types to establish the characters of the genus. However, in our studies on Dothideomycetes, which have now taken more than eight years and $15 \mathrm{PhD}$ students, we have only studied more than 500 genera accepted in Lumbsch \& Huhndorf (2010) and many of the genera can be considered distinct. We still have more than 500 synonymized genera (e.g. in von Arx \& Müller 1975, Müller \& von Arx 1962) to study and these may also be distinct. However, with such huge resources needed to examine the other 500 genera, I believe that if we today find new genera based on molecular data, we can ignore these earlier, poorly described genera as we need to provide platforms for other mycologists to move forward.

My experience also tells me that it is a waste of time to take species types too seriously, as it is often impossible to confirm that the characters of the type loaned, is the same species as the fresh collection one is examining. Colletotrichum gloeosporioides is an excellent example as are Diaporthe and Phomopsis species. In the end the decision for the species comparison is completely subjective. Thus, there is a choice - subjectively use the old names, which may not be the same as the species in hand, or introduce a new species with a new name and disregard the old name. Neither can likely be scientifically confirmed with our present techniques, so neither is wrong nor right, and thus no one should be overtly critical. It is, however, important to move forward, by either naming new species or using names without loaning types, so that we can start to understand the species in a genus, rather than waiting until we, for example, collect a species exactly similar to the type (that in any case, may be phylogenetically different). Otherwise we cannot move forward we will become dinosaurs and mycologists will be regarded as prehistoric creatures. 
I summarize problems of using old names below:

1) I strongly recommend that we try to use old generic names and should examine the types to establish the characters of the genus. However, it will not be possible to loan, or economically feasible to study all generic types and thus many of these can be ignored.

2) Many herbaria will no longer loan herbarium material (PAD - Saccardo, LPS - Spegazzini, UPS and L - Fries and Persoon) and thus they no longer perform their function. We cannot use these names anymore and should either provide epitypes (for genera) even though we cannot see the material or ignore those names altogether (for unclear genera and species)

3) Since most genera are likely to contain cryptic species and we cannot generally sequence the old types, we can ignore most old species names, especially those in speciose genera.

4) Given that in many large genera (e.g. Agaricus, Leptosphaeria, Pleospora), most species are polyphyletic and have been placed in the wrong genera, we can ignore most old species names.

5) When introducing new species, especially in large genera (e.g. those with more than 20 species), it is generally futile to compare a species with the old names, using historical protologues, as we are not even sure we are comparing species in the same genera. Thus, we can ignore most old species names.

6) Loaning types is a slow and difficult process. Even when we compare types at the species level, the conclusions are usually subjective as we cannot sequence the old fungal specimens. Therefore, we can ignore most old species names.

In conclusion, I strongly recommend that we try to use old generic names and should examine the types to establish the characters of the genus. This is especially important with economically important genera (e.g. plant pathogens). However, even at the generic level, this is fraught with problems and many older generic names will need to be ignored. At the species level, we should be able to ignore many old names. We are now in a new molecular era, where we can identify fungal taxa, scientifically using sequence data as compared to subjectively using our eyes. Without names the results of studies become futile (see all the publications using new generation sequencing with $80 \%$ operational taxonomic units (OTUs), where we have no idea about the role of these OTUs). However, if we wait to put old names on these fungi, we will hold up progress and as mycologists we should serve the scientific community and move forward.

\section{Rajesh Jeewon}

Mycologists have experienced that time and time again, given names are subject to changes following an increase in taxonomic knowledge and a better understanding of species relationships. Taxonomy is an evolving science and taxonomists endeavour to obtain a better understanding of the mycological world; so what is in a name? Are there extinct fungal species that we would possibly never ever be able to isolate again? I totally agree that names are the core concept of fungal taxonomy, but would it not be a pity to stick to an archaic system that sometimes does not reflect modern systematics! I have deep respect for the ICN and eminent mycologists who have established names, but whenever there are sufficient taxonomic grounds to justify neglection of old names- let it be and lets move forward in the same way we have considered Latin descriptions for novel species unimportant. I would argue what is more important than old names are species relationships or a reliable classification that reflects evolutionary aspects. Not considering old names does not necessarily mean an end to our current taxonomic concepts, rather a necessity to better organize existing taxonomic information, understand fungal diversity and address fundamental questions in ecology. With DNA sequence data unravelling cryptic species, it would be very likely that if we stick to old names, a number of taxa will be left unnamed or named inappropriately. It is also well known that in many circumstances, incorrect or ambiguous names have been associated with many old taxa, which can be considered as obsolete, or otherwise inconsistent with currently accepted names. These have had to be revisited to enable standardization of species names, avoid erroneous scientific conclusions, and assist in making 
reliable predictions, especially for plant pathogens. It is therefore fundamental for any party to provide accurate information (e.g means of identification, source and proper annotation of specimens and reliable DNA sequence data) if old names have not been considered.

Sticking to old names will continue to be a debate and it is very unlikely that we can find a consensus very soon. Many mycologists experience difficulties loaning materials from various herbariums/institutions. The herbaria are not entirely at fault as they need to safeguard rare materials in appropriate conditions, as many specimens will possibly not be recollected again. For example, one species that has always baffled me is Pestalotia pezizoides De Not., isolated from Vitis vinifera in Milan, Italy. I cannot recall this being recollected and described in the $20^{\text {th }} / 21^{\text {st }}$ century and obviously, it would be sad if this treasure ends up in a dilapidated state with successive loaning. In this era of sophisticated technology and digitalization, where one can simply stay in one place and retrieve information, there should be means to access all details of old names with the click of a mouse! Progress in this aspect has been slow, but is underway and soon examination of old names might become a virtual reality. In many forensic sciences (e.g pathology, medicine, criminology, anthropology), scientists have made great headway in solving enigmatic problems with minute samples. Mycologists should take a leap ahead to devise fast, accurate and reliable methods that would facilitate public availability of DNA and other taxonomic information from minute samples. Obviously one might question the reliability of such information, but if such is the case, then possibly we will have doubt on all existing published literature. The major problem I foresee herein is the cost implication of such an innovation as in many tropical countries, where the majority of most fungi reside, funding for mycology is not a priority.

I am not denying the fact that old names can serve as exemplars and reference material for future studies, but our traditional lines of thinking in taxonomy pertaining to old names should be given a new dimension.

\section{Marc Stadler}

During our previous taxonomic work, which mostly involved studies of xylariaceous macromycetes, it has often been extremely useful to be able to rely on type material. The reason was that our work has heavily relied on chemotaxonomic data and that the secondary metabolites in genera such as Daldinia, Hypoxylon and allies proved to be stable for up to 200 years in the herbarium specimens. Since the family Xylariaceae happens to be a rather highly complicated and diverse group of Ascomycota, and most of their names go back on sexual morph records (i.e. stromatal collections), the study of these herbarium specimens has been crucial. In contrast, their asexual morphs are very difficult, if not impossible to characterise based on morphology alone, and only a few species have been typified. A concise treatment of sexual states will also pave the way to recognise and identify the numerous endophytes that have recently been detected in environmental samples. In the stromatic Xylariaceae it has been highly practical to have herbarium specimens of the type materials at hand, in order to sort out errors and confusions that were based on the previous application of broad generic and species concepts. Most of the relevant type specimens have been located, and the herbaria kindly allowed us to study the material by the highly sensitive HPLC-MS methodology, which does not require more material than is needed for a routine microscopic study. Several examples from our previous work, including some of the Persoon's type specimens in Leiden, as well as numerous materials from BPI, K, NY, S (and when it was still possible to get material from loan, LPS and PAD) have demonstrated the feasibility of this approach (Stadler et al. 1994, 2008a, 2014; Kuhnert et al. 2016).

On the downside, we have come across several specimens that were highly depauperate or among Xylaria, immature stromata or little fungal material were left in the specimen packages. In case of the specimens that were reported by Alfred Möller (1901) from Brazil, some materials were recovered after over 100 years that were actually preserved under ethanol. Duplicates were eventually sent to Stockholm, but those were largely small fragments and often did not contain fertile elements. The specimens soaked in ethanol were not recognisable anymore, and only in the case of Entonaema mesentericum (which was actually transferred to Xylaria in the course of that 
study), was it possible to safely associate the holotype with recently collected specimens by analysing the ethanol for the characteristic chemotaxonomic marker compound Xylaral (cf. Stadler et al. 2008b). Other important specimens like the holotype of the monotypic Xylocrea pyriforme were beyond salvage and it will only be possible to re-collect and recognise this fungus based on Möller's excellent drawings and meticulous description of fresh material. DNA extraction was attempted but not possible from either material (M.S., unpublished results). These examples show that even in macrofungi, it is futile to safely establish the correspondence of old herbarium material, and that it is worthwhile to consider alternatives. However, the alternative should never be to forego any attempt to locate type materials, so long as the current regulations are in place, since this would result in some chaos. I could imagine that similar to the currently established lists of suppressed/rejected vs. protected names (Kirk et al. 2014), another list of lost and "unepitypifiable" type materials could be created that will ultimately facilitate the valuable work on recognition of new fungi and segregation of pathogenic from harmless species mentioned elsewhere herein.

Actually, in my personal opinion, it may be important to keep the current nomenclatural rules stable wherever feasible, because they even sometimes prevent unnecessary splitting and lumping of genera. After all, taxonomy has always been a subjective matter, but it should remain user-friendly! While changes in the species concepts and even at the higher (suprageneric) taxonomic levels will probably never do any serious harm, the genus level is by far the most sensitive. For practical mycologists, as well as for amateur mycologists dealing with edible macrofungi, the situation has become difficult, and many of them do not follow anymore the current rules of taxonomy. Only to name an example, several mushroom field guides have not been updated for years because the authors were apparently reluctant to follow the continuous splitting of genera that were sometimes not or rather tentatively supported by phenotypic data. In these cases, or in case of industrially important and toxicogenic fungi, more nomenclatural stability should clearly be called for.

On the other hand, the application of molecular data (and wherever feasible, polyphasic taxonomic approaches) is absolutely imperative for development of safe diagnostics that allow for recognition of important human, animal and plant pathogens, as well as for the evaluation of true biodiversity in the numerous pantropical species complexes. In conclusion, the situation may be quite different among different user groups, and in general I would propose to follow a pragmatic approach, making decisions on a case-by-case-basis. The examples mentioned above by others clearly demonstrate that the current rules often impede the implementation of innovative taxonomic concepts, so they are not ideal for all purposes anymore. More flexibility is called for. Ultimately, I would not even exclude that the mycological community may eventually decide to establish a new "Mycocode" that is more flexible with respect to complying with the requirements of different user groups. If this were to be realised, the community could for instance try to decide to get rid of the author names, thereby eliminating an incentive that seems to be important for some mycologists who tend to prematurely establish novel taxa, as they will be proud to have their name tags behind the species epithet.

\section{Conclusion}

Mycologists should inevitably acknowledge that the guidelines and practices of resorting to old names requires change, given the vast number of species that remain to be discovered. We argue that old names are not vague philosophical concepts and serve a purpose in fungal taxonomy. However, with the difficulties in loaning specimens and lack of expertise from specialist mycologists, our suggestions provided herein, do not resolve all problems, nor do they offer permanent solutions. We however, believe that our statements will help clarify some of the pertinent problems and enable mycologists to make headway towards a better understanding of fungal taxonomy and its biodiversity. 


\section{Acknowledgements}

Kevin D. Hyde thanks the Chinese Academy of Sciences, project number 2013T2S0030, for the award of Visiting Professorship for Senior International Scientists at Kunming Institute of Botany. AJL Phillips acknowledges support from Biosystems and Integrative Sciences Institute (BioISI, FCT/UID/ Multi/04046/2013). Monika Dayarathne thanks Kalani Hapuaarchchi and Rungtiwa Phookamsak for their helpful comments and advice. The University of Mauritius is acknowledged for support and Mae Fah Luang University is thanked for the offer of a short term Visiting Professor to Dr Rajesh Jeewon in 2016.

\section{References}

Abang MM, Abraham WR, Asiedu R, Hoffmann P et al. 2009 - Secondary metabolite profile and phytotoxic activity of genetically distinct forms of Colletotrichum gloeosporioides from yam (Dioscorea spp.). Mycological Research 113, 130-140.

Alves A, Correia A, Phillips AJL. 2006 - Multi-gene genealogies and morphological data support Diplodia cupressi sp. nov., previously recognized as $D$. pinea $\mathrm{f}$. sp. cupressi, as a distinct species. Fungal Diversity 23, 1-15.

Alves A, Linaldeddu BT, Deidda A, Scanu B, Phillips AJL. 2014 - The complex of Diplodia species associated with Fraxinus and some other woody hosts in Italy and Portugal. Fungal Diversity 67, 143-156.

Aptroot A. 1998 - A world revision of Massarina (Ascomycota) - Nova Hedwigia 89-162.

Ariyawansa HA, Hawksworth DL, Hyde KD, Jones EBG et al. 2014 - Epitypification and neotypification: guidelines with appropriate and inappropriate examples. Fungal Diversity 69, 57-91.

Barghoorn ES, Linder DH. 1944 - Marine fungi: their taxonomy and biology. Farlowia, 1, 395467.

Bensch K, Braun U, Groenewald JZ, Crous PW (2012) The genus Cladosporium. Studies in Mycology 72, 1-401.

Blackwell M. 2011 - The Fungi: 1, 2, 3 ‥ 5.1 million species?. American Journal of Botany. 98, 426-438.

Braun U, Cook RTA. 2012 - Taxonomic Manual of the Erysiphales (Powdery Mildews). CBS Biodiversity Series 11, 1-707.

Braun U. 2000 - Annotated list of Cercospora spp. described by C. Spegazzini. Schlechtendalia 5, 57-79. Braun U. 2013 - Proposals to conserve the teleomorph-typified name Blumeria against the anamorph-typified name Oidium and twenty-two teleomorph-typified powdery mildew species names against competing anamorph-typified names (Ascomycota: Erysiphaceae). Taxon 62, 1328-1331.

Braun U, Crous PW. 2016 - (2415) Proposal to conserve the name Cercospora (Ascomycota: Mycosphaerellaceae) with a conserved type. Taxon 65, 185.

Brock PM, Doring H, Bidartondo MI. 2009 - How to know unknown fungi: the role of a herbarium. New Phytologist 181, 719-724.

Cai L, Hyde KD, Taylor PWJ, Weir B et al. 2009 - A polyphasic approach for studying Colletotrichum. Fungal Diversity 39, 183-204.

Cannon PF, Buddie AG, Bridge PD, de Neergard E, et al. 2012 - Lectera, a new genus of the Plectosphaerellaceae for the legume pathogen Volutella colletotrichoides. Mycokeys 3, 2336.

Castlebury LA, Rossman AY, Jaklitsch WJ, Vasilyeva LN. 2002 - A preliminary overview of the Diaporthales based on large subunit nuclear ribosomal DNA sequences. Mycologia 94, 1017-1031.

Castlebury LA, Farr DF, Rossman AY, Jaklitsch WJ. 2003 - Diaporthe angelicae comb. nov., a modern description and placement of Diaporthopsis in Diaporthe. Mycoscience 44, 203208. 
Cook RTA, Inman AJ, Billings C. 1997 - Identification and classification of powdery mildew anamorphs using light and scanning electron microscopy and host range data. Mycological Research 101, 975-1002.

Correll JC, Guerber JC, Wasilwa LA, Sherrill JF, Morelock TE. 2000 - Inter- and Intraspecific variation in Colletotrichum and mechanisms which affect population structure In: Prusky D, Dickman MB, Freeman S, eds. Colletotrichum: host specificity, pathogenicity, and hostpathogen interactions. St. Paul, Minnesota, USA: 145-170.

Crous PW, Braun U. 2003 - Mycosphaerella and its anamorphs: 1. Names published in Cercospora and Passalora. CBS Biodiversity Series 1, 1-569 CBS-KNAW Fungal Biodiversity Centre, Utrecht, the Netherlands.

Crous PW, Groenewald JZ. 2005 - Hosts, species and genotypes: opinions versus data. Australasian Plant Pathology 34, 463-470.

Crous PW, Palm ME. 1999 - Reassessment of the anamorph genera Botryodiplodia, Dothiorella and Fusicoccum. Sydowia 51, 167-175.

Crous PW, Slippers B, Wingfield MJ, Rheeder J et al. 2006 - Phylogenetic lineages in the Botryosphaeriaceae. Studies in Mycology 55, 235-253.

Damm U, Woudenberg JHC, Cannon PF, Crous PW. 2009. - Colletotrichum species with curved conidia from herbaceous hosts. Fungal Diversity 39, 45-87.

Damm U, Cannon PF, Liu F, et al. 2013 - The Colletotrichum orbiculare species complex: Important pathogens of field crops and weeds. Fungal Diversity 61, 29-59.

Daranagama DA, Camporesi E, Tian Q, Liu XZ et al. 2015 -Anthostomella is polyphyletic comprising several genera in Xylariaceae. Fungal Diversity 73, 203-238.

Daranagama DA, Jones EBG, Liu XZ, To-anun C et al. 2016 - Mycosphere Essays 13 - Do xylariaceous macromycetes make up most of the Xylariomycetidae? Mycosphere 7, 596614.

Diogo ELF, Santos JM, Phillips AJL. 2010 - Phylogeny, morphology and pathogenicity of Diaporthe and Phomopsis species on almond in Portugal. Fungal Diversity 44, 107-115.

Dissanayake AJ, Liu M, Zhang W, Chen Z et al. 2015 - Morphological and molecular characterization of Diaporthe species associated with grapevine trunk disease in China. Fungal Biology 119, 283-294

Farr ML. 1973 - An annotated list of Spegazzini’s fungus taxa. Vol. 1. Bibliotheca Mycologica 35, $1-823$.

Fries EM. 1832 - Systema mycologicum. 3(2). E Mauritii, Greifswald. from vines. Mycotaxon 66, 497-499.

Frisvad JC. 2015 - Taxonomy, chemo diversity and chemo consistency of Aspergillus, Penicillium, and Talaromyces species. Frontiers in Microbiology 5, 773. doi: 10.3389/fmicb.2014.00773

Frisvad JC, Larsen TO, de Vries R, Meijer M et al. 2007 - Secondary metabolite profiling, growth profiles and other tools for species recognition and important Aspergillus mycotoxins. Studies in Mycology 59, 31-37.

Gao YH, Liu, F, Cai, L. 2016. - Unravelling Diaporthe species associated with Camellia. Systematics and Biodiversity 14, 102-117.

Gomes RR, Glienke C, Videira SIR, Lombard L et al. 2013 - Diaporthe: a genus of endophytic, saprobic and plant pathogenic fungi. Persoonia 31, 1-41.

Groenewald JZ, Nakashima C, Nishikawa J, Shin HD et al. 2013 - Species concepts in Cercospora: spotting the weeds among the roses. Studies in Mycology 75, 115-170.

Guarro J, Gené J. Stchigel A.M. 1999 - Developments in fungal taxonomy. Clinical Microbiology Reviews 12, 454-500.

Guba EF. 1961 - Monograph of Pestalotia and Monochaetia. Harvard University Press, Cambridge.

Hawksworth DL. 2001 - The magnitude of fungal diversity: the 1.5 million species estimate revisited. Mycological Research 105, 1422-1432. 
Hawksworth DL. 2004 - Fungal diversity and its implications for genetic resource collections. Studies in Mycology 50, 9-18.

Hawksworth DL. 2014 - Possible house-keeping and other draft proposals to clarify or enhance the naming of fungi within the International Code of Nomenclature for algae, fungi, and plants (ICN). IMA Fungus 5, 31-37.

Hawksworth DL. 2015 - Proposals to clarify and enhance the naming of fungi under the International Code of Nomenclature for algae, fungi, and plants. IMA Fungus 6, 199-205.

Hennings P. 1903 - Squamotubera P. Henn. n. gen. Xylariaceaeum. Hedwigia 42, 308-309.

Hibbett DS, Binder M, Bischoff JF, Blackwell M et al. 2007 - A higher-level phylogenetic classification of the Fungi. Mycological Research 111, 509-547.

Hirayama K, Tanaka K. 2011 - Taxonomic revision of Lophiostoma and Lophiotrema based on reevaluation of morphological characters and molecular analyses. Mycoscience 52, 401412.

Holmgren PK, Holmgren NH, Barnett LC. 1990 - Index Herbariorum, Part I: The Herbaria of the World. $8^{\text {th }}$ ed. Regnum Veg. 120. Bronx, NY: The New York Botanical Garden, 693p.

Hyde KD, Cai L, McKenzie EHC, Yang YL et al. 2009 - Colletotrichum: a catalogue of confusion. Fungal Diversity 39, 1-17

Hyde KD, Jones EBG, Liu JK, Ariyawansa HA et al. 2013 - Families of Dothideomycetes. Fungal Diversity 63, 1-313.

Hyde KD, Nilsson RH, Alias SA, Ariyawansa HA et al. 2014 - One stop shop: backbones trees for important phytopathogenic genera: I. Fungal Diversity 67, 21-125.

Index Fungorum, 2016 - http://www.indexfungorum.org/Names/Names.asp. (accessed: AugustNovember 2016).

Ingold CT. 1934 - Triscelophorus monosporus n. gen., n. sp., an aquatic hyphomycete. Transactions of the British mycological Society 26, 148-152.

Jayasiri SC, Hyde KD, Ariyawansa HA, Bhat J et al. 2015 - The Faces of Fungi database: fungal names linked with morphology, phylogeny and human impacts. Fungal Diversity 74, 3-18.

Jayawardena RS, Ariyawansa HA, Singtripop C, Li YM et al. 2014 - A re-assessment of Elsinoaceae (Myriangiales, Dothideomycetes). Phytotaxa 176: 120-138

Jayawardena RS, Hyde KD, Jeewon R, Liu XH et al. 2016a - Why it is important to correctly name Colletotrichum species? Mycosphere 7, 1076-1092.

Jayawardena RS, Hyde KD, Damm U, Cai L et al. 2016b - Notes on currently accepted species of Colletotrichum. Mycosphere 7, 1192-1260.

Jeewon R, Liew ECY, Simpson JA, Hodgkiss IJ, Hyde KD. 2003 - Phylogenetic significance of morphological characters in the taxonomy of Pestalotiopsis species. Molecular Phylogenetics and Evolution 27, 372-383.

Jeewon R, Liew ECY, Hyde KD. 2004 - Phylogenetic evaluation of species nomenclature of Pestalotiopsis in relation to host association. Fungal Diversity 17, 39-55.

Jeewon R, Hyde KD. 2016 - Establishing species boundaries and new taxa among fungi: recommendations to resolve taxonomic ambiguities. Mycosphere 7, 1669-1677.

Jørgensen PM. 2014 - Notes on the new Example 9 in Article 9.8 of the International Code of Nomenclature for algae, fungi, and plants. Taxon 63, 132-133.

Kajitani Y, Kanematsu S. 2000 - Diaporthe kyushuensis sp. nov., the teleomorph of the causal fungus of grapevine swelling arm in Japan, and its anamorph Phomopsis vitimegaspora. Mycoscience 41, 111-114.

Kirk PM, Stalpers JA, Braun U, Crous PW et al. 2014 - A without-prejudice list of generic names of fungi for protection under the international Code of nomenclature for algae, fungi, and plants. IMA Fungus 4, 381-443.

Kuhnert E, Sir EB, Lambert C, Hyde KD et al. 2017 - Phylogenetic and chemotaxonomic resolution of the genus Annulohypoxylon (Xylariaceae) including four new species. Fungal Diversity in press (Doi: 10.1007/s13225-016-0377-6) 
Kuo KC, Leu LS. 1998 - Phomopsis vitimegaspora: a new pathogenic Phomopsis from vines. Mycotaxon 66, 497-499.

Landeros F, Iturriaga T, Rodríguez A, Vargas-Amado G, Guzmán-Dávalos L. 2015 - Advances in the phylogeny of Helvella (Fungi: Ascomycota), inferred from nuclear ribosomal LSU sequences and morphological data. Revista Mexicana de Biodiversidad 86, 856-871.

Larsson E. Jacobsson S. 2004 - Controversy over Hygrophorus cossus settled using ITS sequence data from 200 year-old type material. Mycological Research 108, 781-786.

Li GJ, Hyde KD, Zhao RN, Hongsanan S et al. 2016 - Fungal diversity notes 253-366: taxonomic and phylogenetic contributions to fungal taxa. Fungal Diversity 78, 1-237.

Liu F, Damm U, Cai L, et al. 2013 - Species of the Colletotrichum gloeosporioides complex associated with anthracnose diseases of Proteaceae. Fungal Diversity 61, 89-105.

Liu JK, Phookamsak R, Doilom M, Wikee S et al. 2012 - Towards a natural classification of Botryosphaeriales. Fungal Diversity 57, 149-210.

Liu JK, Hyde KD, Jones EBG, Ariyawansa HA et al. 2015 - Fungal diversity notes 1-110: taxonomic and phylogenetic contributions to fungal species. Fungal Diversity 72, 1-197

Lombard L, Houbraken J, Decock C, Samson RA et al. 2016 - Generic hyper-diversity in Stachybotriaceae. Persoonia 36, 156-246.

Lu BS, Hyde KD. 2000b - A world monograph of Anthostomella. Fungal Diversity Research Series 4, 1-376.

Lumbsch HT, Huhndorf SM. 2010 - Myconet Volume 14. Part One. Outline of Ascomycota 2009. Part Two. Notes on Ascomycete Systematics. Nos. 4751-5113. Fieldiana Life Earth Science 1, 1-64.

Maharachchikumbura SSN, Guo LD, Chukeatirote E, Bahkali AH, Hyde KD. 2011 - Pestalotiopsis - morphology, phylogeny, biochemistry and diversity. Fungal Diversity 50, 167-187.

Maharachchikumbura SSN, Guo LD, Cai L, Chukeatirote E et al. 2012 - A multi-locus backbone tree for Pestalotiopsis, with a polyphasic characterization of 14 new species. Fungal Diversity 56, 95-129.

Maharachchikumbura SSN, Hyde KD, Groenewald JZ, Xu J, Crous PW. 2014 - Pestalotiopsis revisited. Studies of Mycology 79, 121-186.

Maharachchikumbura SS, Hyde KD, Jones EBG, McKenzie EHC et al. 2015 - Towards a natural classification and backbone tree for Sordariomycetes. Fungal Diversity 72, 199-301.

Maharachchikumbura SSN, Guo LD, Liu Z, Hyde KD. 2016 - Pseudopestalotiopsis ignota and Ps. camelliae spp. nov. associated with grey blight disease of tea in China. Mycological Progress 15, 1-7.

McNeill J, Barrie FR. Buck WR, Demoulin V et al. 2012 - International Code of Nomenclature for algae, fungi, and plants (Melbourne Code) adopted by the Eighteenth International Botanical Congress Melbourne, Australia, July 2011. [Regnum Vegetabile No. 154.] Königsten: Koeltz Scientific Books.

Mctavish CK, Fulbright DW, Jarosz AM. 2016 - Do Phomopsis isolates cause cankers associated with spruce decline? Phytopathology 106, S6-S6.

Müller E, von Arx JA. 1962 - Die Gattungen der didymosporen Pyrenomyceten. Beiträge zur Kryptogamenflora der Schweiz. 11, 1-922.

Nag Raj TR. 1993 - Coelomycetous anamorphs with appendage bearing conidia. Mycologue

Norphanphoun C, Maharachchikumbura SSN, Daranagama A, Bulgakov TS et al. 2015 - Towards a backbone tree for Seimatosporium, with S. physocarpi sp. nov. Mycosphere 6, 385-400.

Pang KL. 2012 - Phylogeny of the marine Sordariomycetes. In: Jones EBG, Pang KL (eds) Marine fungi and fungal-like organisms. Walter de Gruyter $\mathrm{GmbH} \& \mathrm{Co}$. KG, Berlin/Boston, pp $35-47$.

Pang KL, Jones EBG, Vrijmoed LLP. 2008 - Autecology of Antennospora (Ascomycota, Fungi) and its phylogeny. Raffles Bulletin Zoology 19, 1-10.

Paul YS, Kapoor JN. 1985 - Taxonomy of anamorphs of Erysiphaceae. Indianm Phytopathology $38,761-763$. 
Pearce CA, Hyde KD. 1994 - The genus Phyllachora from Australia: observations on taxa from Callistemon species. Mycological Research 98, 1393-1401.

Pearce CA, Reddell P, Hyde KD. 1999 - A revision of Phyllachora (Ascomycotina) on hosts in the angiosperm family Asclepiadaceae, including P. gloriana sp. nov., on Tylophora benthamii from Australia. Fungal Diversity 3, 123-138.

Phillips AJL, Alves A, Correia A, Luque J. 2005 - Two new species of Botryosphaeria with brown, 1-septate ascospores and Dothiorella anamorphs Mycologia, 97, 513-529.

Phillips AJL, Lopes J, Abdollahzadeh J, Bobev S, Alves A. 2012 - Resolving the Diplodia complex on apple and other Rosaceae hosts. Persoonia 29, 29-38.

Phillips AJL, Alves A, Abdollahzadeh J, Slippers B et al. 2013 - The Botryosphaeriaceae: genera and species known from culture. Studies in Mycology 76, 51-167.

Pintye A, Bereczky Z, Kovács GM, Nagy GL et al. 2012 - No Indication of Strict Host Associations in a Widespread Mycoparasite: Grapevine Powdery Mildew (Erysiphe necator) is attacked by phylogenetically distant Ampelomyces strains in the field. Phytopathology Publications. Canada 102, 707-716.

Promputtha I, Lumyong S, Vijaykrishna D, McKenzie EHC et al. (2007). A phylogenetic evaluation of whether endophytes become saprotrophs at host senescence. Microbial Ecology 53, 579-590.

Ravichandra NG. 2013 - Fundamentals of plant pathology. Phi Learning Pvt. Ltd., India 151-152.

Rensburg JCJ van, Lamprecht SC, Groenewald JZ, Castlebury LA, Crous PW. 2006 Characterization of Phomopsis spp. associated with die-back of rooibos (Aspalathus linearis) in South Africa. Studies in Mycology 55, 65-74.

Rossman A, Udayanga D, Castlebury LA, Hyde KD. 2014 - (2304) Proposal to conserve the name Diaporthe eres against twenty-one competing names (Ascomycota: Diaporthales: Diaporthaceae). Taxon 63, 934-935.

Rossman AY, Crous PW, Hyde KD, Hawksworth DL et al 2015 - Recommended names for pleomorphic genera in Dothideomycetes. IMA fungus 6, 507-523.

Samson RA, Noonim P, Meijer M, Houbraken J et al. 2007 - Diagnostic tools to identify black aspergilli. Studies in Mycology 59, 129-145.

Sandoval-Denis M, Guarro J, Cano-Lira JF, Sutton DA et al. 2016 - Phylogeny and taxonomic revision of Microascaceae with emphasis on synnematous fungi. Studies in Mycology 83, 193-233

Santos MD, Fonseca-Boiteux ME, Boiteux LS, Câmara PE, Dianese JC. 2016 - ITS-phylogeny and taxonomy of Phyllachora species on native Myrtacae from the Brazilian Cerrado. Mycologia online, doi: 10.3852/16-025

Seifert P, Ansmann A, Mattis I, Wandinger U et al. 2010 - Saharan dust and heterogeneous ice formation: Eleven years of cloud observations at a central-European EARLINET site. Journal of Geophysical Research 115, D20201, doi:10.1029/2009JD013222.

Shear CL, Dodge BO. 1927 - Life histories and heterothallism of the red bread-mold fungi of the Monila sitophila group. Journal of Agricultural Research. 34, 1019-1042.

Slippers B, Crous PW, Denman S, Coutinho TA et al. 2004 - Combined multiple gene genealogies and phenotypic characters differentiate several species previously identified as Botryosphaeria dothidea. Mycologia 96, 83-101.

Stadler M, Ju YM, Rogers JD. 2004 - Chemotaxonomy of Entonaema, Rhopalostroma and other Xylariaceae. Mycological Research 108, 239-256.

Stadler M, Fournier J, Beltrán-Tejera E, Granmo A. 2008a - The "red Hypoxylons" of the temperate and subtropical Northern Hemisphere. North American Fungi 3, 73-125.

Stadler M, Fournier J, Læssøe T, Lechat C et al. 2008b - Recognition of hypoxyloid and xylarioid Entonaema species from a comparison of holomorphic morphology, HPLC profiles, and ribosomal DNA sequences. Mycological Progress 7, 53-73.

Stadler M, Læssøe T, Fournier J, Decock C et al. 2014 - A polyphasic taxonomy of Daldinia (Xylariaceae) Studies in Mycology 77, 1-143. 
Steyaert RL. 1949 - Contributions à l'étude monographique de Pestalotia de Not. et Monochaetia Sacc. (Truncatella gen. nov. et Pestalotiopsis gen. nov.). Bulletin du Jardin Botanique de l'État à Bruxelles 19, 285-354

Steyaert RL. 1953a - New and old species of Pestalotiopsis. Transactions of the British Mycological Society 36, 81-89

Steyaert RL. 1953b - Pestalotiopsis from the Gold Coast and Togoland. Transactions of the British Mycological Society 36, 235-242

Steyaert RL. 1955 - Pestalotia, Pestalotiopsis et Truncatella. Bulletin du Jardin Botanique de l'État à Bruxelles 25, 191-199.

Steyaert RL. 1956 - A reply and an appeal to Professor Guba. Mycologia 48, 767-768

Steyaert RL. 1961 - Type specimens of Spegazzini's collections in the Pestalotiopsis and related genera (Fungi Imperfecti: Melanconiales). Darwinia (Buenos Aires) 12, 157-190

Sutherland, G.K. 1915 - New marine fungi on Pelvetia. New Phytologist 14, 33-42.

Sutherland, G.K. 1916 - Marine Fungi Imperfecti. New Phytologist 15, 35-48.

Sutton BC. 1980 - The coelomycetes: fungi imperfecti with pycnidia, acervular and stromata. Commonwealth Mycological Institute, Kew.

Tai FL. 1935 - Two new species of Neurospora. Mycologia 27, 328-330.

Talbot PHB. 1971 - Principles of Fungal Taxonomy. The Macmillan Press, London. 274p.

Taylor JW, Jacobson DJ, Kroken S, Kasuga T et al. 2000 - Phylogenetic species recognition and species concepts in fungi. Fungal Genetics and Biology 31, 21-32.

Tedersoo L, Bahram M, Põlme S, Kõljalg U et al. 2014 - Fungal biogeography. Global diversity and geography of soil fungi. Science 346(6213), 1256688.

Thambugala KM, Hyde KD, Tanaka K, Tian Q et al. 2015 - Towards a natural classification and backbone tree for Lophiostomataceae, Floricolaceae, and Amorosiaceae fam. nov. Fungal Diversity 74, 199-266.

Turner BC, Perkins DD, Fairfield A. 2001 - Neurospora from natural populations: a global study. Fungal Genetics and Biology 32, 67-92.

Udayanga D, Liu X, McKenzie EHC, Chukeatirote E et al. 2011 - The genus Phomopsis: biology, applications, species concepts and names of common phytopathogens. Fungal Diversity 50, $189-225$.

Udayanga D, Liu XZ, Crous PW, McKenzie EHC et al. 2012 - A multi-locus phylogenetic evaluation of Diaporthe (Phomopsis). Fungal Diversity 56, 157-217.

Udayanga D, Castlebury LA, Rossman AY, Chukeatirote E, Hyde KD. 2014 - Insights into the genus Diaporthe: phylogenetic species delimitation in the $D$. eres species complex. Fungal Diversity 67, 203-229.

van Niekerk JM, Groenewald JZ, Farr DF, Fourie PH et al. 2005 - Reassessment of Phomopsis species on grapevines. Australasian Plant Pathology 34, 27-39.

Vellinga EC, Kuyper TW, Ammirati J, Desjardin DE et al. 2015 - Six simple guidelines for introducing new genera of fungi. IMA Fungus 6, 68-65.

von Arx JA, Müller E. 1975 - A re-evaluation of the bitunicate ascomycetes with keys to families and genera. Studies in Mycology 9, 1-159.

Wang X, Li YX, Dong HX, Jia XZ, Zhang XY. 2015 - First Report of Botryosphaeria dothidea causing canker of Acer platanoides in China. Plant Disease 99, 1857-1857.

Wehmeyer LE. 1933 - The genus Diaporthe Nitschke and its segregates. University of Michigan Studies Scientific Series 9, 1-349.

Weir B, Johnston PR, Damm U. 2012 - The Colletotrichum gloeosporioides species complex. Studies in Mycology 73, 115-180.

Wijayawardene NN, Bhat DJ, Hyde KD, Camporesi E et al. 2014a-Camarosporium sensu stricto in Pleosporinae, Pleosporales with two new species. Phytotaxa 183, 16-26.

Wijayawardene NN, Hyde KD, Bhat DJ, Camporesi E et al. 2014b - Camarosporium-like species are polyphyletic in Pleosporales; introducing Paracamarosporium and Pseudocamarosporium gen. nov. in Montagnulaceae. Cryptogamie Mycologie 35, 177-198. 
Wijayawardene NN, Crous PW, Kirk PM, Hawksworth DL et al. 2014c - Naming and outline of Dothideomycetes - 2014 including proposals for the protection or suppression of generic names. Fungal Diversity 69, 1-55.

Yang T, Groenewald JZ, Cheewangkoon R, Jami F, Abdollahzadeh J et al. 2016 - Families, genera, and species of Botryosphaeriales. In Press, Uncorrected Proof, http://dx.doi.org/10.1016/j.funbio.2016.11.001 